REVIEW

\title{
Adverse psychological effects of corticosteroids in children and adolescents
}

\author{
F A Stuart, T Y Segal, S Keady
}

Arch Dis Child 2005;90:500-506. doi: 10.1136/adc.2003.041541

Children and adolescents treated with oral, inhaled, and intravenous corticosteroids (CS) may experience adverse psychological side effects (APSE), including psychotic symptoms. These can occur at any point during treatment, including withdrawal. In this paper the literature on these effects in children and adults is reviewed. From the evidence available, it is not possible to give reliable estimates for incidence or prevalence of APSE, nor clear risk factors. Some evidence is reported to suggest that oral dexamethasone treatment may carry a higher risk of APSE than other CS, but this requires further investigation. There is evidence from the adult literature that higher CS doses increase the risk of APSE. However, the dose response effect is not straightforward or predictable for individuals or groups. This is likely to be a reflection of the complex effects of CS on the central nervous system and the probable interplay between individual susceptibility, disease factors, and external environmental stressors in the emergence of APSE. More research is required to further our understanding of the adverse effects of these clinically valuable agents.

See end of article for authors' affiliations

Correspondence to: Dr F A Stuart, Specialist Registrar in Child and Adolescent Psychiatry, Child and Family Department, Tavistock Centre, 120 Belsize Lane, London NW3 5BA, UK; fionnuala@doctors.org.uk

Accepted 15 January 2005

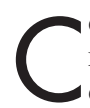
orticosteroids (CS) are used in the treatment of a wide variety of conditions in children and adolescents including asthma, rheumatic diseases, and central nervous system tumours. Since their introduction in the 1950s, CS have been associated with adverse psychological side effects (APSE), ranging from psychotic symptoms to mild changes in mood and cognition, in addition to their well known physical side effects. This is perhaps not surprising given the long recognised association between excessive endogenous CS levels and altered mood and behaviour. Rates of psychiatric disturbance (predominantly depression and anxiety) in adults with Cushing disease are between $57 \%$ and $78 \%,{ }^{1-3}$ while children with this disorder show rates of $44 \%$, with compulsive behaviours predominating. ${ }^{4}$

Most research on APSE of CS treatment has been in adult populations with a focus on dramatic behavioural reactions (often vaguely described as "steroid psychosis") reported in case series and case reports. ${ }^{56}$ In addition to case reports (table 1), the child and adolescent research includes a number of controlled prospective trials (table 2) providing information on less severe APSE, such as depressive symptoms and mild cognitive effects. Clinical trials of CS in adults and children have sometimes recorded APSE alongside other side effects, although they are often poorly described and defined.

This review is based on a literature search of published articles on this topic, prioritising research involving CS preparations in common current usage. We will give an overview of the varied APSE attributed to CS in children and adolescents, discuss possible risk factors and mechanisms, consider the clinical implications, and make recommendations for future research. Evidence from the adult literature will be drawn on where relevant.

\section{SEVERE ADVERSE PSYCHOLOGICAL EFFECTS INCLUDING PSYCHOSIS}

Prevalence and presenting features

Severe APSE, often referred to as "steroid psychosis", are estimated to occur in 5-6\% of adult patients. ${ }^{8}$ Equivalent figures are not yet available for paediatric populations. Rates of $25-60 \%$ for "psychiatric disturbance" from early paediatric studies ${ }^{89}$ cannot reliably be extrapolated, as "psychiatric disturbance" was generally poorly defined and the studies largely involved treatment with cortisone and ACTH. Historically, there was a view that severe APSE, especially psychotic symptoms, did not occur in children. ${ }^{8}{ }^{10}$ We identified 16 case reports of severe APSE in children and adolescents, over half of which included psychotic symptoms (table 1). Such APSE have also been reported in one case series of children treated with pulsed intravenous methylprednisolone ${ }^{11}$ (table 2), and in one, as yet unpublished, prospective trial in children with acute lymphoblastic leukaemia (ALL), both of which are discussed later.

Reviewing this data, severe APSE in children and adolescents usually emerge within days of onset of treatment. As in adults, affective/mood symptoms (emotional lability, grandiosity, pressured speech, suicidality, irritability) are the most common, sometimes accompanied by psychotic symptoms (persecutory delusions, auditory hallucinations). There can be periods of altered conscious level and disorientation, and symptoms may vary within the episode. Duration varies widely between a few days, remitting on cessation/reduction of the CS dose, to a small minority persisting after discontinuation, also in keeping with adult research findings. ${ }^{72}$

\section{Difficulties in diagnosis and confounding factors}

CS are often prescribed in response to a deterioration in the underlying condition, raising 


\begin{tabular}{|c|c|c|c|c|c|c|}
\hline Reference & Age & Sex & Ethnicity & Diagnosis & CS type + dose & Clinical presentation \\
\hline Hall, $1979^{50}$ & 17 & $\mathrm{~F}$ & $\mathrm{~N} / \mathrm{K}$ & Asthma & $\begin{array}{l}\text { ACTH oral } 40 \text { units/day } \\
\text { Prednisolone oral } \\
40-60 \mathrm{mg} / \text { day }\end{array}$ & $\begin{array}{l}\text { Fluctuating presentation including insomnia, } \\
\text { distractability, emotional lability, grandiosity, } \\
\text { pressured speech, agitation, hypomania }\end{array}$ \\
\hline Ducore, $1983^{34}$ & 15 & M & White & ALL & $\begin{array}{l}\text { Prednisolone oral } \\
90 \mathrm{mg} / \text { day + intermittent IV } \\
\text { hydrocortisone as part of } \\
\text { chemotherapy protocol }\end{array}$ & $\begin{array}{l}\text { Initially anxiety and fear of dying proceeding to } \\
\text { frank psychosis with delusions of grandiosity, } \\
\text { persecutory delusions, disinhibited behaviour, } \\
\text { fluctuating levels of alertness, intermittent } \\
\text { disorientation }\end{array}$ \\
\hline Ducore, $1983^{34}$ & 13 & $\mathrm{~F}$ & Black & ALL & $\begin{array}{l}\text { Prednisolone oral } \\
40 \mathrm{mg} / \mathrm{m}^{2} / \text { day }\end{array}$ & $\begin{array}{l}\text { Disinhibition, regressive behaviour, apathy, } \\
\text { incontinence, "frankly psychotic" behaviour }\end{array}$ \\
\hline Lewis, $1983^{14}$ & 5.5 & $\mathrm{~F}$ & $\mathrm{~N} / \mathrm{K}$ & Asthma & $\begin{array}{l}\text { Budesonide inhaled } \\
100 \mu \mathrm{g} \text { twice daily }\end{array}$ & Hyperactive, aggressive, severe insomnia \\
\hline Meyboom, $1988^{15}$ & 9 & M & $N / K$ & Asthma & $\begin{array}{l}\text { Budesonide inhaled } \\
100 \mu \mathrm{g} \text { twice daily added } \\
\text { to nasal beclomethasone }\end{array}$ & $\begin{array}{l}\text { Hyperactive behaviour, impaired psychomotor } \\
\text { activity and strongly increased appetite }\end{array}$ \\
\hline Connett, $1991^{16}$ & 2.5 & M & $N / K$ & Asthma & $\begin{array}{l}\text { Budesonide (inhaled via } \\
\text { spacer and mask) } 400 \mu \mathrm{g} \\
\text { twice daily }\end{array}$ & $\begin{array}{l}\text { Severe temper tantrums, "miserable and } \\
\text { uncooperative" }\end{array}$ \\
\hline Connett, $1991^{16}$ & 3 & M & $N / K$ & Asthma & Budesonide as above & Insomnia, screaming, aggression \\
\hline Connett, $1991^{16}$ & 2 & M & $N / K$ & Asthma & Budesonide as above & Hyperactive, undisciplined, insomnia \\
\hline Connett, $1991^{16}$ & 2.5 & M & $\mathrm{N} / \mathrm{K}$ & Asthma & $\begin{array}{l}\text { Budesonide as above, } \\
\text { but thrice daily }\end{array}$ & $\begin{array}{l}\text { Secondary enuresis, aggression and violence } \\
\text { towards sister, insomnia }\end{array}$ \\
\hline Watanabe, $1994^{24}$ & 17 & $\mathrm{~F}$ & $\mathrm{~N} / \mathrm{K}$ & ALL & $\begin{array}{l}\text { Dexamethasone } 15 \mathrm{mg} / \\
\text { day for } 3 / 52 \text {, then dose } \\
\text { tapered for } 2 / 52 \text { as part } \\
\text { of chemotherapy protocol }\end{array}$ & $\begin{array}{l}\text { Symptoms emerged during tapering: } \\
\text { psychomotor agitation, marked insomnia, } \\
\text { euphoria, disinhibition, pressured speech, } \\
\text { labile affect, flight of ideas }\end{array}$ \\
\hline Watanabe, $1994^{24}$ & 13 & $\mathrm{~F}$ & $\mathrm{~N} / \mathrm{K}$ & ALL & $\begin{array}{l}\text { Dexamethasone } 15 \mathrm{mg} / \\
\text { day for } 3 / 52 \text {, then dose } \\
\text { tapered for } 1 / 52 \text { as part } \\
\text { of chemotherapy protocol }\end{array}$ & $\begin{array}{l}\text { Symptoms emerged during tapering: } \\
\text { hypochondriasis and fear of dying, panic } \\
\text { symptoms, sadness, separation anxiety }\end{array}$ \\
\hline Turktas, $1997^{17}$ & 14 & M & $\mathrm{N} / \mathrm{K}$ & Asthma & $\begin{array}{l}\text { Beclomethasone inhaled } \\
1500 \mu \mathrm{g} / \text { day }\end{array}$ & $\begin{array}{l}\text { Insomnia, visual and auditory hallucinations, } \\
\text { pressured speech, labile affect, decreased } \\
\text { attention and memory }\end{array}$ \\
\hline Dawson, $1998^{18}$ & 8 & $\mathrm{~F}$ & Black & Asthma & $\begin{array}{l}\text { Prednisolone oral } 20 \mathrm{mg} \\
\text { twice daily for } 5 \text { days }\end{array}$ & $\begin{array}{l}\text { Hyperactivity, aggression, insomnia } \\
\text { progressing to emotional lability, visual } \\
\text { hallucinations, pressured speech, episodic } \\
\text { crying spells }\end{array}$ \\
\hline Beshay, $1998^{51}$ & 12 & $M$ & White & Ulcerative colitis & $\begin{array}{l}\text { Long term oral } \\
\text { prednisolone Rx up } \\
\text { to } 60 \mathrm{mg} / \text { day }\end{array}$ & $\begin{array}{l}\text { Recurrent episodes of irritability, insomnia, } \\
\text { agitation, physical aggression, auditory } \\
\text { hallucinations, depressive symptoms, social } \\
\text { withdrawal }\end{array}$ \\
\hline Kramer, $1999^{25}$ & 14 & $\mathrm{~F}$ & $\begin{array}{l}\text { Black African } \\
\text { American }\end{array}$ & ALL & $\begin{array}{l}\text { Dexamethasone oral } \\
24 \mathrm{mg} / \text { day for } 21 / 7 \\
\text { then } 10 / 7 \text { taper }\end{array}$ & $\begin{array}{l}\text { Symptoms during tapering: fluctuating } \\
\text { presentation with disorientation, auditory and } \\
\text { visual hallucinations, grandiose delusions, } \\
\text { suicidality }\end{array}$ \\
\hline Ingram, $2003^{48}$ & 2 & M & White & ALL, BMT, GVHD & $\begin{array}{l}\text { Methylpred } 2 \mathrm{mg} / \mathrm{kg} / \text { day } \\
\text { in } 3 \text { divided doses }\end{array}$ & $\begin{array}{l}\text { Irritable, visual hallucinations, crying, head } \\
\text { banging }\end{array}$ \\
\hline
\end{tabular}

the possibility that psychiatric symptoms are secondary to this deterioration, as part of an acute confusional state, rather than CS treatment per se. Indeed, Halper has questioned the popularly held view that adults with systemic lupus erythematosus (SLE) are more prone to severe APSE, pointing out that SLE patients in the quoted studies were often acutely unwell and had CNS symptoms which were difficult to distinguish from CS induced APSE. ${ }^{5}$ Other authors, reviewing severe APSE in adult cancer patients, propose that medical complications and narcotic analgesics play an important contributory role. ${ }^{13}$
From the case reports of severe APSE in children and adolescents reviewed here, evidence supporting CS playing a causative role is as follows: APSE appeared shortly after the commencement of CS treatment, resolved swiftly on dose reduction or cessation of CS treatment (dose reduction/ cessation was in response to APSE rather than improvement in condition), ${ }^{14-18}$ and reappeared on dose increase; ${ }^{16}$ physical examination and/or laboratory tests excluded deteriorating medical condition or concomitant medication toxicity as confounding factors; ${ }^{14-18}$ and stereotyped APSE appeared on re-exposure to the CS. ${ }^{16}$ Some case reports were complicated 
by features such as multiple concomitant medications and significant deterioration in physical health. Nevertheless, in the majority, features such as stereotyped symptoms on CS re-exposure, suggested that CS treatment was contributory, if not singly responsible, for the APSE.

\section{Is there a dose-response relation?}

Several case series of adult patients show an increasing incidence of severe APSE with increasing CS dose. ${ }^{5}$ The Boston Collaborative Drug Surveillance Programme, a multicentre prospective case series, recorded acute psychiatric reactions in $1.3 \%$ of patients receiving $\leqslant 40 \mathrm{mg}$ oral prednisolone/day, $4.6 \%$ of patients receiving $41-80 \mathrm{mg}$, and $18.4 \%$ of patients receiving $\geqslant 80 \mathrm{mg} .{ }^{19}$ However, data from this and other adult case series suggest that it is not a straightforward dose-response effect, in that there was no predictable relation between the timing, severity, or duration of APSE and the timing, dosage, and duration of CS treatment. ${ }^{5712}$ Previous reviewers have suggested that "disease related factors" may be important in the pathogenesis of severe APSE. ${ }^{5}$ A prospective double blind study of normal adult volunteers prescribed $80 \mathrm{mg}$ oral prednisolone/day for five days reported no severe APSE, which would appear to support this theory (although there were reports of individualised milder reactions, either during the treatment period or on withdrawal). ${ }^{20}$ However, the sample size (12) and the short treatment period could also explain the absence of severe APSE.

Large prospective case series in paediatric populations are lacking. In the prospective controlled trials to date there have been no reports of severe APSE. This could be explained by the fact that the only trials with large samples involved low dose CS treatment schedules (table 2). ${ }^{21}{ }^{22}$ In the published case reports of severe APSE where the treatment was oral CS, all doses were of $\geqslant 40 \mathrm{mg}$ of prednisolone or prednisolone equivalent/day. While this might support APSE occurring at higher CS doses, confounding factors such as publication bias demand caution when extrapolating potential risk factors from case reports.

Nevertheless, the seven case reports involving inhaled CS suggest further complications in the dose-response relation. Dramatic APSE occurred at standard paediatric doses (when delivery methods were taken into account), some within 48 hours of commencement of treatment. ${ }^{14-17}$ APSE on inhaled CS have been attributed to withdrawal effects from cessation of preceding oral CS treatment. ${ }^{7}$ This was not the case in these reports. Five of these patients were under 6 years, ${ }^{14}{ }^{16}$ and poor inhaler technique leading to increased systemic absorption has been proposed as an explanation. ${ }^{5}$ However, in three of the cases no APSE emerged during prior treatment with oral prednisolone or intravenous hydrocortisone, which are likely to have produced higher systemic CS levels. APSE ceased either on cessation of the inhaled CS or switching to an alternative inhaled CS.

\section{Are certain CS more likely to cause severe APSE?}

Halper flags up the lack of systematic studies in adults or children addressing this issue. ${ }^{5}$ APSE account for $9 \%$ of all adverse reactions for dexamethasone, compared to $6 \%$ for prednisolone according to UK regulatory drug safety databases (adult and child data are combined). ${ }^{23}$ In a recent UK Medical Research Council randomised controlled trial of 1600 child and adolescent patients with ALL, "behavioural toxicity" was reported in $6 \%$ of the dexamethasone group $\left(6.5 \mathrm{mg} / \mathrm{m}^{2}\right.$ orally in two divided doses for four weeks during induction therapy) compared with $1 \%$ in the prednisolone group $\left(40 \mathrm{mg} / \mathrm{m}^{2}\right.$ orally in two divided doses in same conditions). Behavioural changes ranged from "mood swings" through to "severe depression and violence towards self or others", and three cases of "delusional psychosis" in the dexamethasone group. Cessation of steroids lead to rapid resolution of symptoms. Most patients on dexamethasone with severe problems were switched to prednisolone with no reported significant recurrence of behavioural problems. However, clinicians were not blind to steroid allocation. Importantly, there was a significant reduction of isolated CNS relapse of ALL in the dexamethasone group (unpublished data, personal communication).

In three case reports, adolescent girls developed psychotic reactions during the tapering phase of dexamethasone treatment, but did not experience APSE on high dose prednisolone (up to $90 \mathrm{mg} /$ day), either before or after dexamethasone treatment. ${ }^{24} 25$ However, one of the girls had shown no APSE to a similar previous course of dexamethasone, ${ }^{25}$ again raising the possibility that "disease related factors" are also required for development of severe APSE. There is therefore some evidence that dexamethasone may be more associated with severe APSE than prednisolone in children and adolescents, but further research is required to clarify this.

\section{ADVERSE PSYCHOLOGICAL EFFECTS APPEARING ON WITHDRAWAL OF CORTICOSTEROIDS}

"Psychological dependency" on CS due to their euphoric effects is widely recognised both anecdotally and in published literature. ${ }^{51326}$ It is now clear, however, that both florid and milder APSE can occur during tapering or after cessation of CS treatment. ${ }^{51327}$ Mood and affect changes are most common in adults, followed by delirium and psychotic states. ${ }^{26}$ Previous reviewers have concluded that a significant proportion of the reported suicidal behaviour associated with CS treatment in adults occurs during withdrawal. ${ }^{5}$ CS related suicidal ideation has been reported in children and adolescents, but the data are too limited to draw conclusions about an association with CS withdrawal.

In a large prospective case series of children with acute rheumatic diseases receiving pulsed intravenous methylprednisolone (MP), 10\% experienced "neuropsychiatric" reactions, ranging from "hyperactivity" to "psychosis" (table 2). ${ }^{11}$ In over half these cases, APSE appeared $>24$ hours after the infusion and so may represent withdrawal reactions. ${ }^{5}$ APSE were picked up by parent/child or clinician reports, not standardised assessment schedules. Some appeared after several non-eventful infusions and analysis is also complicated by the fact that a proportion of children were taking oral CS concomitantly. Researchers were not blind; however, a causative role of MP in the behavioural reactions was potentially supported by a proportion showing stereotyped reoccurrence following subsequent pulses and by significant improvements in some children when the MP dose was decreased or the time interval between infusions was increased.

Methodological flaws and the specificity of treatment and underlying disorders in this trial demand caution in extrapolation of its results. However, taken together with the case reports of symptoms appearing on tapering of dexamethasone, ${ }^{24} 25$ it suggests that children and adolescents, like adults, are vulnerable to APSE on withdrawal from CS treatment.

\section{MINOR/MODERATE MOOD AND BEHAVIOURAL EFFECTS AND ADVERSE COGNITIVE EFFECTS}

Less dramatic CS related APSE have generally received little attention in the adult literature. ${ }^{5}$ One difficulty is detangling these APSE from the "normal" responses of stress and anxiety provoked by the underlying illness for which CS are prescribed. The designs of controlled prospective trials in children and adolescents (table 2 ) have attempted to address this issue. In some the child acted as their own control, 
Table 2 Trials and case series

\begin{tabular}{|c|c|c|c|c|c|c|}
\hline Reference & $\begin{array}{l}\mathrm{n} / \text { age in years } \\
\text { Design }\end{array}$ & Disease & Drug/daily dose & Standardised tests used & Main findings & Limitations \\
\hline De La Riva, $1957^{\circ}$ & $\begin{array}{l}34 / 4-14 \\
\text { Open } \\
\text { Case series }\end{array}$ & Various & ACTH/ cortisone & $\begin{array}{l}\text { None } \\
\text { Relatives' reports and } \\
\text { psychiatric assessments }\end{array}$ & $\begin{array}{l}61 \% \text { of sample had } \\
\text { psychiatric SE: } 59 \% \\
\text { "depressive", } 41 \% \\
\text { "euphoric" } \\
\text { Depressed group had } \\
\text { usually shown euphoric } \\
\text { symptoms first }\end{array}$ & $\begin{array}{l}\text { No standardised tests } \\
\text { used } \\
\text { Little detail given } \\
\text { about nature of } \\
\text { psychiatric SE }\end{array}$ \\
\hline Harris, $1986^{30}$ & $\begin{array}{l}\text { 16/4-16 } \\
\text { Prospective } \\
\text { Child as own } \\
\text { control } \\
\text { Repeated } \\
\text { measures }\end{array}$ & $\begin{array}{l}\text { ALL (14) } \\
\text { Lymphoma (2) }\end{array}$ & $\begin{array}{l}\text { Prednisolone (pred) } \\
40-60 \mathrm{mg} / \text { day oral } \\
\text { for } 4 / 52 \text { every } 4 / 12\end{array}$ & $\begin{array}{l}\text { CSI } \\
\text { CDI } \\
\text { SHSQ }\end{array}$ & $\begin{array}{l}\text { Night-waking increased } \\
\text { on pred (NS). Irritability, } \\
\text { tearfulness, } \\
\text { argumentativeness, mild } \\
\text { depressive symptoms and } \\
\text { tiredness increased when } \\
\text { on pred }\end{array}$ & $\begin{array}{l}\text { CDI is for use in } \\
\text { children over } 8 \text { y of } \\
\text { age, excluding } 6 \text { of } \\
\text { their sample. Not } \\
\text { blinded }\end{array}$ \\
\hline Suess, $1986^{22}$ & $\begin{array}{l}\text { 120/9-18 } \\
\text { Prospective } \\
\text { Comparison } \\
\text { Single blind }\end{array}$ & Asthma & $\begin{array}{l}\text { Non-asthmatic } \\
\text { controls } v \text { theophylline } \\
\text { only } v \text { theoph + } \\
\text { pred (alt days } \\
16 \mathrm{mg} / \text { day) }\end{array}$ & $\begin{array}{l}\text { BVRT } \\
\text { WMS }\end{array}$ & $\begin{array}{l}\text { Increased delayed } \\
\text { memory recall in steroid } \\
\text { groups at } 6-8 \mathrm{~h} \text {. No } \\
\text { significant difference } \\
\text { between groups at } \\
22-24 \mathrm{~h} \text { or } 46-48 \mathrm{~h} \\
\text { post-dose }\end{array}$ & $\begin{array}{l}\text { No steroid alone } \\
\text { group so? differences } \\
\text { due to steroid- } \\
\text { theophylline } \\
\text { interaction }\end{array}$ \\
\hline Bender, $1988^{31}$ & $\begin{array}{l}27 / 8-16 \\
\text { Prospective } \\
\text { Comparison } \\
H D \vee L D\end{array}$ & Asthma & $\begin{array}{l}\text { Prednisolone (oral) } \\
3.3 \mathrm{mg} / \text { day (low } \\
\text { dose, LD) v } \\
62 \mathrm{mg} / \text { day } \\
\text { (high dose, HD) }\end{array}$ & $\begin{array}{l}\text { CDI, CMAS, CPT, DRT, } \\
\text { SRT, ultrasonic motion } \\
\text { detector for hyperactivity, } \\
\text { static steadiness tester for } \\
\text { fine motor control }\end{array}$ & $\begin{array}{l}\text { HD: decreased memory, } \\
\text { increased anxiety + } \\
\text { depressive symptoms. } \\
\text { No differences in } \\
\text { impulsiveness, } \\
\text { hyperactivity, motor } \\
\text { unsteadiness }\end{array}$ & $\begin{array}{l}\text { No information } \\
\text { gathered from } \\
\text { parents/carers. } \\
\text { Children not asked re } \\
\text { other psychiatric Sx }\end{array}$ \\
\hline Bender, $1991^{32}$ & $\begin{array}{l}32 / 8-16 \\
\text { Prospective } \\
\text { Comparison } \\
H D \vee L D\end{array}$ & Asthma & $\begin{array}{l}\text { Prednisolone (oral) } \\
7 \mathrm{mg} / \text { day (LD) } \mathrm{v} \\
62 \mathrm{mg} / \text { day (HD) }\end{array}$ & $\begin{array}{l}\text { PPVT, CGAS, FGAS, } \\
\text { CDI, CMAS, CPT, SRT, } \\
\text { ultrasonic motion detector } \\
\text { for hyperactivity, static } \\
\text { steadiness tester for fine } \\
\text { motor control }\end{array}$ & $\begin{array}{l}\text { Confirmed above results } \\
\text { No predisposing factors } \\
\text { identified }\end{array}$ & $\begin{array}{l}\text { Children not asked re } \\
\text { other psychiatric Sx.? } \\
\text { Atypical sample in } \\
\text { terms of social class }\end{array}$ \\
\hline Nall $1992^{29}$ & $\begin{array}{l}\text { 19/7-15 } \\
\text { Prospective } \\
\text { Child as own } \\
\text { control }\end{array}$ & Asthma & $\begin{array}{l}\text { Prednisolone (oral) } \\
1-2 \mathrm{mg} / \mathrm{kg} / \text { day } \\
\text { on or off }\end{array}$ & $\begin{array}{l}\text { WRAT-R } \\
\text { BRP-2 }\end{array}$ & $\begin{array}{l}\text { No difference in } \\
\text { cognitive tests or } \\
\text { behaviour scale score }\end{array}$ & Researchers not blind \\
\hline Drigan, $1992^{33}$ & $\begin{array}{l}38 / 2.5-8.8 \\
\text { Prospective } \\
\text { Comparison } \\
\text { Repeated } \\
\text { measures }\end{array}$ & ALL & $\begin{array}{l}\text { Chemo }+ \text { pred (oral) } \\
40 \mathrm{mg} / \mathrm{m}^{2} / \text { day } \\
(\mathrm{Ch}+\mathrm{LD}) \mathrm{chem}+\text { pred } \\
120 \mathrm{mg} / \mathrm{m}^{2} / \text { day } \\
(\mathrm{Ch}+\mathrm{HD}) \mathrm{v} \text { chemo alone }\end{array}$ & $\begin{array}{l}\text { Conners Parent-Teacher } \\
\text { Hyperkinesis Index } \\
\text { I (amended) administered } \\
\text { to parents only } \\
\text { e }\end{array}$ & $\begin{array}{l}\text { Adverse changes in } \\
\text { attention/hyperactivity, } \\
\text { emotionality, sleep } \\
\text { disturbance, depressed } \\
\text { mood, listlessness + peer } \\
\text { relations in Ch+LD and } \\
C h+H D v C h \text { alone } \\
\text { No differences in } \\
\text { behaviours between } \\
C h+H D \vee C h+L D\end{array}$ & $\begin{array}{l}\text { Small matched sample } \\
\text { size may have limited } \\
\text { ability to detect } \\
\text { difference between LD } \\
\text { and HD groups }\end{array}$ \\
\hline Bender, $1998^{21}$ & $\begin{array}{l}\text { 102/6-17 } \\
\text { Prospective } \\
\text { Double-blind } \\
\text { controlled } \\
\text { multi-centre }\end{array}$ & Asthma & $\begin{array}{l}\text { Beclomethasone (inh) } \\
2 \times 50 \mu \mathrm{g} \text { qds+ } \\
\text { placebo tab } v \\
\text { theophylline+placebo } \\
\text { inhaler }\end{array}$ & $\begin{array}{l}\text { CBCL, WISC-R, W-J, } \\
\text { SCWT, WCST, I, BRVRT, } \\
\text { SDLT, RAVLT }\end{array}$ & $\begin{array}{l}\text { No significant differences } \\
\text { in cognitive tests or } \\
\text { behaviour between } \\
\text { groups }\end{array}$ & $\begin{array}{l}\text { Sample did not include } \\
\text { children under } 6 \text { who } \\
\text { may be most } \\
\text { vulnerable to APSE } \\
\text { from inhaled steroids }\end{array}$ \\
\hline $\begin{array}{l}\text { Klein-Gitelman, } \\
\text { 1998"1 }\end{array}$ & $\begin{array}{l}213 / 1-18 \\
\text { Case series }\end{array}$ & $\begin{array}{l}\text { Acute rheumatic } \\
\text { disease }\end{array}$ & $\begin{array}{l}\text { Intermittent pulsed IV } \\
\text { methylprednisolone } \\
30 \mathrm{mg} / \mathrm{kg}\end{array}$ & None & $\begin{array}{l}10 \% \text { of sample had } \\
\text { adverse psychological } \\
\mathrm{SE} \text {, including psychosis. } \\
\text { Majority appeared post } \\
\text { pulse and ceased within } \\
48 \mathrm{~h}\end{array}$ & $\begin{array}{l}\text { Case series rather } \\
\text { than controlled study }\end{array}$ \\
\hline Soliday, $1999^{28}$ & $\begin{array}{l}\text { 10/ages not } \\
\text { known } \\
\text { Prospective } \\
\text { Child as own } \\
\text { control }\end{array}$ & $\begin{array}{l}\text { Steroid sensitive } \\
\text { idiopathic nephritic } \\
\text { syndrome }\end{array}$ & $\begin{array}{l}\text { "High dose" } \\
\text { prednisolone therapy } \\
\text { (oral) }\end{array}$ & $\mathrm{CBCL}$ & $\begin{array}{l}\text { Anxious, depressive and } \\
\text { aggressive behavioural } \\
\text { changes at doses of } \\
>1 \mathrm{mg} / \mathrm{kg} / 48 \mathrm{~h}\end{array}$ & $\begin{array}{l}\text { Small sample } \\
\text { Not blinded }\end{array}$ \\
\hline
\end{tabular}


comparing test scores "on" and "off" CS. ${ }^{28-30}$ In others mean scores were compared between groups differing in treatment only by the presence of CS or by CS dose..$^{21} 2{ }^{31-33}$ Samples were often asthmatic children and subjects were usually "medically stable" during testing. However, numbers were generally small and few trials were even single blind. Differences in age groups and treatments make it difficult to compare or combine results and few studies gave information on the functional impact of any behavioural or cognitive changes noted.

Generally, children "on" CS showed increased levels of depressive and anxiety symptoms compared to children "off" CS, but at levels which fell below the "clinical caseness" threshold of the assessment tools used..$^{28-32}$ Insomnia, tearfulness, irritability, argumentative behaviour, and tiredness were more common in children on CS than controls. $^{28}{ }^{30} 33$ However, when "high" and "low" dose CS treatments were compared, the differences in behavioural and mood symptoms between the groups were less marked..$^{32}{ }^{33}$ It is therefore not possible to extract a dose threshold for these APSE in children. Results from adult studies suggest that they occur at doses on or above $20 \mathrm{mg}$ prednisolone equivalent/day. ${ }^{27}$

"Reversible deficits in declarative memory" (memory typically tested by recall of lists of words/facts) are the most frequently reported findings in adult research into CS related cognitive effects, including trials using "normal" subjects. The actual frequency of occurrence of these effects in adult patients treated with CS is not known, but there is a growing recognition that these adverse effects have been underappreciated. $^{5}$

Results from child and adolescent prospective trials are conflicting. Some show diminished mean verbal memory (comparable to declarative memory) in "high" CS dose (61.5 mg prednisolone/day) groups compared to "low dose" (3-7 mg prednisolone/day) groups. ${ }^{31}{ }^{32}$ In two trials no difference in mean scores of cognitive tests (or behavioural checklists) between CS treated children and controls was found. ${ }^{21}{ }^{29}$ One was the only trial in which the CS treatment was inhaled rather than oral, ${ }^{21}$ and the other involved a relatively small sample. ${ }^{29}$ Another trial showed delayed memory recall in the CS treated group at 6-8 hours postdose, but not at 22 hours, ${ }^{22}$ suggesting reversibility similar to that seen in adults.

\section{RISK FACTORS FOR APSE}

In adults, reports from earlier studies that female gender and a history of past psychiatric disturbance increased the risk of APSE, whether severe or "minor", have been called into question by recent analysis, as have reports that certain medical conditions predispose to CS induced APSE. ${ }^{57}$ Results from controlled prospective trials in children and adolescents suggest a slightly increased risk of APSE in girls, ${ }^{32}{ }^{33}$ and younger children, ${ }^{30}$ but these are not conclusive. Regarding past psychiatric history, authors from one prospective trial attempted to explore individual and family psychosocial dysfunction as a risk factor for APSE. ${ }^{32}$ However, the methods used, together with the small differences observed, render their conclusions questionable. There was no history of past psychological disturbance in the majority of paediatric case reports, although in four the family histories were highly positive. ${ }^{24}$ As to whether certain underlying medical conditions render children and adolescents more susceptible to CS related APSE, this is largely unanswered. Prospective studies merely reflect the CS treated conditions studied to date and extrapolation from case reports is again likely to be contaminated by publication bias. A history of adverse cutaneous reactions to other drugs was found to be predictive for all adverse effects to CS in the prospective case series involving pulsed intravenous MP. ${ }^{11}$

\section{POTENTIAL MECHANISMS UNDERLYING APSE}

Through research on endogenous and exogenous CS in animals and humans we know that CS exert a bewilderingly large range of effects on the nervous system. They have varying effects on the neurotransmitters serotonin and dopamine, and adrenal steroid receptors are expressed in many different regions of the brain. ${ }^{5}$ On a molecular level, CS have both direct, rapid, non-genomic effects such as binding to receptors or altering membrane permeability, as well as indirect, genomically mediated effects such as repression of gene transcription..$^{35}$ However, we are still some way from knowing which effects underlie specific APSE.

There has been considerable focus on hippocampal damage as a potential mechanism underlying APSE. Functionally this model is attractive as the hippocampus, as part of the limbic system, is intimately involved in regulation of the emotions and emotional lability is a frequent feature of APSE. It also plays a major role in memory, particularly the forms of memory (episodic, declarative) found to be adversely affected in patients treated with CS, patients with Cushing disease, and normal human volunteers given CS. ${ }^{535}{ }^{37}$ It is known to express high levels of adrenal steroid receptors, ${ }^{38}{ }^{39}$ and animal and human studies have shown a correlation between high levels of endogenous CS, hippocampal damage and atrophy, and cognitive dysfunction. ${ }^{50}$ The "cascade effect" further proposes that damage to the hippocampus adversely affects its ability to provide negative feedback on glucocorticoid levels to the hypothalamic-pituitary-adrenal (HPA) axis, leading to increased levels and hence more damage. ${ }^{51}$

How reversible this damage is, is not yet clear, nor how it occurs. It may be mediated by increases in excitatory amino acids and serotonin, ${ }^{35} 42$ or it may also be attributable to glucocorticoids rendering hippocampal neurones more vulnerable to other insults such as ischaemia, through impaired neuronal glucose uptake. ${ }^{35}$ If exogenous CS render hippocampal neurones more vulnerable to insults, this could perhaps explain some cases of inter- and intra-patient variability with respect to APSE. That is, APSE might only arise if there is both exposure to CS and potential insults to hippocampal neurones arising from the disease process, which could represent the speculated "disease related factors". However, while there have been studies linking exogenous CS with hippocampal atrophy in rats and primates, ${ }^{5}$ definitive links have not yet been found in humans. Human adult studies suggesting that "working memory" (generally considered a frontal lobe function) is more sensitive than declarative memory (hippocampal) to exogenous CS administration, also point to other areas of the brain being involved in APSE in addition to the hippocampus. ${ }^{53}$

We also know that CS can improve cognitive functioning adversely affected by the underlying illness in both children and adults. ${ }^{54}$ Halper has proposed that there may be different CS dose-response curves for hippocampal damage versus beneficial anti-inflammatory (or other) effects in CS responsive illnesses associated with cognitive dysfunction. ${ }^{5}$ Studies involving cognitive testing of normal young adults whose cortisol levels have been pharmacologically manipulated also suggest that certain levels of CS are necessary for learning and memory. ${ }^{46}$

The picture is further complicated by the lack of knowledge regarding whether exogenous CS gain access to the same organs and cellular sites as are occupied by endogenous CS. ${ }^{5}$ Studies in rats suggest that dexamethasone is more substantially taken up by the pituitary than other brain regions and may have little access to hippocampal neurones. ${ }^{39}$ Prednisolone is structurally more similar to cortisol and 
corticosterone than dexamethasone and so might be expected to be more readily taken up, but systematic studies investigating this and, more generally, links between the pharmacokinetic properties of different CS, brain neurochemistry, and APSE are lacking."

As well as speculated "disease related factors", perhaps there are other factors which may contribute to the expression of APSE. While case reports generally document any abnormal laboratory test results, the level of detail is usually not sufficient to exclude other CS side effects such as hyperglycaemia as contributors to psychological disturbance. One case report described a father and son showing very similar dramatic behavioural reactions to inhaled budesonide (the child's episode predated the father's by a year), raising the possibility of underlying genetic factors. ${ }^{15}$ An intriguing double blind case study of an adult patient requiring intermittent CS treatment for renal disease suggested that APSE only developed when CS treatment coincided with environmental stressors. ${ }^{46}$

Thus, while there is still a great deal of uncertainty, the current findings suggest that the emergence of APSE, whether severe or minor, is likely to involve an interplay between individual predisposing factors, disease related factors, environmental stresses, and the pharmacokinetic properties of the CS treatment.

\section{CLINICAL IMPLICATIONS AND TREATMENT OF APSE}

Because of their valuable therapeutic effects, CS are likely to continue to play an important role in the treatment of many conditions in children and adolescents. Paediatric clinicians, especially those from specialties where CS prescribing plays a major role, need to be alert to the possibility of APSE arising at any point during CS treatment, including withdrawal. Parents and children should be forewarned of these potential side effects in the same measured way that they are forewarned of the potentially serious physical side effects of CS. Proactive questioning about mood and behavioural symptoms is indicated, as stigma ${ }^{27}$ and difficulty in recognition (especially in younger children) may limit spontaneous reporting of psychological symptoms.

Current evidence suggests that, in the majority of cases, APSE respond to dose reduction, switching to an alternative CS preparation, or cessation of CS treatment. If symptoms worsen rather than improve on reduction/cessation, it may be that a withdrawal reaction has been triggered in addition. An adult case report suggested that reintroduction of low dose CS may be effective in these cases. ${ }^{47}$ Clearly it is also important to screen carefully for infection, toxicity from other drugs, or other metabolic disturbances which could be causative or additive to the psychological disturbance.

There are examples from both adult and paediatric case reports of various psychoactive medications, for example, benzodiazepines, neuroleptics, and antidepressants, being used to treat APSE. ${ }^{1824253435}$ Treatment outcomes are variable; for example, there are reports that tricyclic antidepressants can actually make symptoms worse. ${ }^{48}$ The mood stabiliser lithium has been used prophylactically. ${ }^{5} 2435$ However, potential nephrotoxicity, the need for serum monitoring, and evidence that one episode of APSE does not necessarily predict future episodes, render this treatment questionable. Consultation with child and adolescent psychiatrists and paediatric pharmacists is recommended if psychoactive medications are being considered. One-to-one nursing with mental health trained staff and limiting stimuli and also have an important role in the management of cases of severe APSE and may lessen the need for psychoactive medication.

\section{RECOMMENDATIONS FOR FUTURE RESEARCH}

Authors of a recent review on CS use in the management of paediatric central nervous system (CNS) tumours comment that "the beneficial effects of relief of symptoms attributable to raised ICP (intracranial pressure) must be balanced by the frequently observed severe mood and behavioural changes" (our italics).$^{49}$ No data were provided to support this statement, nor were any found in our literature search. This discrepancy between clinical recognition of CS related APSE and actual published data is not confined to CNS tumours, and must be addressed if we are to arrive at reliable estimates of incidence and gain a better understanding of risk factors.

Double blind design trials investigating CS related APSE are difficult, due to a number of factors including: risk of serious physical side effects, limited range of alternative treatment options, changes in physical appearance, and the likely need for large sample sizes to pick up severe APSE. Furthermore, comparison of mean scores can miss out dramatic individual variation within groups. Perhaps the most realistic way of increasing the available data on this important topic would be the inclusion, into large prospective clinical trials involving CS treatment, of standardised assessments by blinded mental health trained assessors for both "minor" and more severe APSE. Smaller qualitative studies may also have a role, particularly in getting a better picture of the functional impact of APSE. Assessments of APSE should always extend into the withdrawal period.

Further elucidation of the underlying mechanisms of APSE is likely to come from the complimentary field of research into the psychological effects of endogenous CS, from more detailed studies exploring the links between APSE, brain neurochemistry, and CS pharmacokinetics, and from research investigating mechanisms for all effects of CS, including therapeutic effects. ${ }^{36}$

\section{ACKNOWLEDGEMENT}

Grateful thanks are extended to Dr Rob Senior, Consultant Child and Adolescent Psychiatrist, Tavistock Clinic for his contributions to the early drafts of this manuscript.

\section{Authors' affiliations \\ F A Stuart, Tavistock Centre, London, UK \\ T Y Segal, S Keady, University College of London Hospital, London, UK \\ Competing interests: none declared}

\section{APPENDIX}

BMT, Bone Marrow Transplant.

BRP-2, Behavior Rating Profile (Brown and Hammill, 1990). BVRT, Benton Visual Retention Test (Benton, 1974).

BRVRT, Benton Revised Visual Retention Test.

CBCL, Child Behaviour Checklist (Achenbach, 1991). ${ }^{52}$

CDI, Children's Depression Inventory (Kovacs, 1978).

CGAS, Child Global Assessment Scale (Shaffer et al, 1983). ${ }^{53}$

CMAS, revised Children's Manifest Anxiety Scale (Reynolds and Richmond, 1985).

CPT, Continuous Performance Test (Rosvold et al, 1956).

CSI, Corticosteroid Symptom Inventory (Harris et al, 1986).

DRT, Delayed Responding Test (Bender et al, 1988).

FGAS, Family Global Assessment Scale (Mraezek et al, 1985)..$^{54}$

GVHD, graft versus host disease.

PPVT, Peabody Picture Vocabulary Test (Dunn and Dunn, 1981).

RAVLT, Rey Auditory Verbal Learning Test.

SCWT, Stroop Color and Word Test.

SDLT, Serial Digit Learning Test.

SHSQ, Sleep Problems and Sleep Habits Questionnaire (Anders, 1980). 
SRT, Selective Reminding Test (Buschke, 1973).

TT, Target Test.

W-J, Woodcock-Johnson Psychoeducational Battery

WCST, Wisconsin Card Sorting Test.

WISC-R, Weschler Intelligence Scale for Children-Revised.

WMS, Weschler Memory Scale (Weschler and Stone, 1974).

WRAT-R, Wide Range Achievement Test-Revised (Jastak and Wilkinson, 1984).

It was not possible to obtain complete references for all tests listed.

\section{REFERENCES}

1 Kelly WF. Psychiatric aspects of Cushing's syndrome. QJM 1996;89:543-51.

2 Loosen PT, Chambliss B, DeBold CR, et al. Psychiatric phenomenology in Cushing's disease. Pharmacopsychiatry 1992;25:192-8.

3 Dorn LD, Burgess ES, Dubbert B, et al. Psychopathology in patients with endogenous Cushing's syndrome: 'atypical' or melancholic features. Clin Endocrinol 1995;43:433-42

4 Devoe DJ, Miller WL, Conte FA, et al. Long-term outcome for children and adolescents following transphenoidal surgery for Cushing disease. I Clin Endocrinol Metab 1997:82:3196-202.

5 Halper JP. Corticosteroids and behavioural disturbances. In: Lin AN, Paget SA, eds. Principles of corticosteroid therapy. London: Arnold, 2002:174-201.

6 Patten SB, Neutel Cl. Corticosteroid-induced adverse psychiatric effects: incidence, diagnosis and management. Drug Safety 2000;22:111-22.

7 Ling MHM, Perry PJ, Tsuang MT. Side effects of corticosteroid therapy: psychiatric aspects. Arch Gen Psychiatry 1981;38:471-7.

8 Satel SL. Mental status changes in children receiving glucocorticoids: review of the literature. Clin Pediatr 1990;29:382-8.

9 De la Riva GE. Psychic and somatic changes observed in allergic children after prolonged steroid therapy. South Med J 1958;51:865-8.

10 Milgrom H, Bender BG. Psychologic side effects of therapy with corticosteroids. Am Rev Respir Dis 1993;147:471-3.

11 Klein-Gitelman MS, Pachman LM. Intravenous corticosteroids: adverse reactions are more variable than expected in children. J Rheumatol 1998;25:1995-2003.

12 Lewis DA, Smith RE. Steroid-induced psychiatric syndromes. J Affec Dis 1983;5:319-32.

13 Steifel FC, Breitbart WS, Holland JC. Corticosteroids in cancer: neuropsychiatric complications. Cancer Invest 1989;7:479-91.

14 Lewis LD, Cochrane GM. Psychosis in a child inhaling budesonide. Lancet 1983;2:634.

15 Meyboom RH, de Graaf-Breederveld N. Budesonide and psychiatric side effects. Ann Intern Med 1988; 109:683.

16 Connett G, Lenney W. Inhaled budesonide and behavioural disturbances. Lancet 1991;338:634-5.

17 Turktas I, Gucuyener K, Ozden A. Medication-induced psychotic reaction. J Am Acad Child Adolesc Psychiatry 1997:36:1017-18.

18 Dawson KL, Carter ER. A steroid-induced acute psychosis in a child with asthma. Pediatr Pulmonol 1998;26:362-4.

19 The Boston Collaborative Drug Surveillance Program. Acute adverse reactions to prednisone in relation to dosage. Clin Pharmacol Ther 1972;13:694-8.

20 Wolkowitz OM, Rubinow D, Doran AR, et al. Prednisone effects on neurochemistry and behaviour. Arch Gen Psychiatry 1990;47:963-8.

21 Bender BG, Ikle DN, DuHamel T, et al. Neuropsychological and behavioural changes in asthmatic children treated with beclomethasone diproprionate versus theophylline. Pediatrics 1998;101:355-60.

22 Suess WM, Stump N, Chai $\mathrm{H}$, et al. Mnemonic effects of asthma medication in children. J Asthma 1986;23:291-6.

23 Medicines Health, Regulatory Authority (MHRA), Committee on Safety of Medicines (CSM). Drug analysis print. Prednisolone/dexamethasone, CDROM. London (version 4.1).

24 Watanabe TK, Sylvester CE, Manaligod JM. Mania or panic associated with dexamethasone chemotherapy in adolescents. J Adolesc Health 1994; 15:345-7.

25 Kramer TM, Cottingham EM. Risperidone in the treatment of steroid-induced psychosis. J Child Adolesc Psychopharmacol 1999;9:315-16.
26 Fricchione G, Ayyala M, Holmes VF. Steroid withdrawal psychiatric syndromes. Ann Clin Psychiatry 1989;1:99-108.

27 Reckart MD, Eisendrath SJ. Exogenous corticosteroid effects on mood and cognition: case presentations. Int J Psychosom 1990;37:57-61.

28 Soliday E, Grey S, Lande MB. Behavioural effects of corticosteroids in steroidsensitive nephritic syndrome. Pediatrics 1999;104:e51.

29 Nall M, Corbett M, Mcloughlin J, et al. Impact of short-term oral steroid use upon children's school achievement and behavior. Ann Allergy 1992;69:218-20.

30 Harris JC, Carel CA, Rosenberg LA, et al. Intermittent high dose corticosteroid treatment in children with cancer: behavioral and emotional consequences. $J$ Am Acad Child Adolesc Psychiatry 1986;25:120-4.

31 Bender BG, Lerner JA, Kollasch E. Mood and memory changes in asthmatic children receiving corticosteroids. J Am Acad Child Adolesc Psychiatry 1988;27:720-5.

32 Bender BG, Lerner JA, Poland JE. Association between corticosteroids and psychologic change in hospitalized asthmatic children. Ann Allergy 1991;66:414-19.

33 Drigan R, Spirito A, Gelber RD. Behavioral effects of corticosteroids in children with acute lymphoblastic leukemia. Med Pediatr Oncol 1992;20:13-21.

34 Ducore JM, Waller DA, Emslie G, et al. Acute psychosis complicating induction therapy for acute lymphoblastic leukemia. J Pediatr 1983:103:477-80

35 Wolkowitz OM, Reus VI, Canick J, et al. Glucorticoid medication, memory and steroid psychosis in medical illness. Ann N Y Acad Sci 1997;823:81-96.

36 Schacke H, Wolf-Dietrich D, Asadullah K. Mechanisms involved in the side effects of glucocorticoids. Pharmacol Ther 2002;96:23-43.

37 Wolkowitz OM. Prospective controlled studies of the behavioural and biological effects of exogenous corticosteroids. Psychoneuroendocrinology 1994; 19:233-55

38 Sapolsky RM, McEwen BS. Down regulation of neural corticosterone receptors by corticosterone and dexamethasone. Brain Res 1985:339:161-5.

39 McEwen BS. The brain is an important target of adrenal steroid actions. A comparison of synthetic and natural steroids. Ann NY Acad Sci 1997;823:201-13.

40 Brown ES, Rush AJ, McEwen BS. Hippocampal remodelling and damage by corticosteroids. Implications for mood disorders. Neuropsychopharmacology 1999;21:474-84

41 Sapolsky RM, Krey LC, McEwen BS. The neuroendocrinology of stress and aging: the glucocorticoid cascade hypothesis. Endocr Rev 1986;7:284-301.

42 Orchinik M. Carroll SS, Yi-Huey L, et al. Heterogeneity of hippocampal $\mathrm{GABA}_{A}$ receptors: regulation by corticosterone. J Neurosci 2001;21:330-9.

43 Lupien SJ, Gillin CJ, Hauger RL. Working memory is more sensitive than declarative memory to the acute effects of corticosteroids: a dose-response study in humans. Behav Neurosci 1999;113:420-30.

44 Taylor SE, Garralda ME, Tudor-Williams G, et al. An organic cause of neuropsychiatric illness in adolescence. Lancet 2003;361:572.

45 Lupien SJ, Wilkinson CW, Briere S, et al. The modulatory effects of corticosteroids on cognition: studies in young human populations. Psychoneuroendocrinology 2002;27:401-16.

46 Carpenter WT, Gruen PH. Cortisol's effect on human mental functioning. J Clin Psychopharmacol 1982;2:91-101.

47 Hassanyeh F, Murray RB, Rogers H. Adrenocortical suppression presenting with agitated depression, morbid jealousy, and a dementia like state. Br J Psychiatry 1991;159:870-1.

48 Ingram DG, Hagerman TM. Promethazine treatment of steroid-induced psychosis in a child. Ann Pharmacother 2003;37:1036-9.

49 Glaser AW, Buxton N, Walker D. Corticosteroids in the management of central nervous system tumours. Arch Dis Child 1997;76:76-8.

50 Hall RCW, Popkin MK, Stickney RN, et al. Presentation of the steroid psychoses. J Nerv Ment Dis 1979;167:229-36.

51 Beshay H, Pumariega AJ. Sertraline treatment of mood disorder associated with prednisone: a case report. J Child Adolesc Psychopharmacol 1998:8:187-93.

52 Achenbach TM. Manual for the Child Behavior Checklist/4-18 and 1991 profile. Department of Psychiatry, University of Vermont, Burlington, VT.

53 Shaffer D, Gould M, Brasic J, et al. A children's global assessment scale (GAS). Arch Gen Psychiatry 1983;40:1228-31.

54 Mrazek D, Masterson J. Family Global Assessment Scale (FGAS): initial reliability and validity. Presented at the meeting of the American Academy of Child Psychiatry, San Antonio, Texas, October, 1985. 